\title{
On corporate diversity : open answer to false promises, a response to Red Hat.
}

\author{
Camille Akmut
}

September 27, 2019

\begin{abstract}
A response to Red Hat's recent corporate diversity message.

"They gained the right to vote, but only so once no social change could be achieved through voting anymore.

These gentlemen allowed them into their universities, but only so once '[inner] experiences' and 'understanding' had replaced scientific analysis within the various social sciences and humanities (cf. Dilthey, and even 'loving understanding' under the pen of Bollnow!); and the goal to build critical minds had taken a back seat, to be replaced by a largely irrational, powerless and disarming worldview."
\end{abstract}

(Ulrike Meinhof, on women's liberation in "False consciousness". Trans.) 
That corporate diversity was always based on empty promises should have escaped only but the not-so-bright :

It came late, i.e. at a point when it had no negative impact on companies anymore, and when they happened to recruit women or minorities significantly more competent than the rest - they could in addition claim progressive values and liberal airs.

And, who, indeed, would say not to such a deal! A philosophy truly of no costs, and only benefits.

But, these half-smart executives, devoid of education in all of the useful disciplines of the mind, cannot and should not expect to be able to sell us their moral fables without a slap-back.

No different than other companies, Red Hat has recently made the world a gift of its very own version of diversity, this most peculiar philosophy of corporate doxa.

1. What has Red Hat done since becoming a part of IBM to seek justice for Lynn Conway?

Hypothesis : nothing.

2. When will Red Hat publish full, raw statistics of its hiring practices to allow independent research and statistical analysis to be undertaken?

Hypothesis : doing so would no doubt reveal large gaps between their practices and discourse, actual acts and promises. We showed so much in the case of SoundCloud ${ }^{1}$; and were only able to do so by creating a dataset based on unofficial employee data.

3. From firsthand knowledge, we know that some Red Hat employees are hired through connections alone. (What anyone would call by its name, nepotism.) In practice, this means these employees skipped the entire technical parts of the hiring process and got through a simple social gathering at the end.

How does this exactly fit inside Red Hat's diversity policies, if at all? How does Red Hat reconcile complex topics like diversity and meritocracy?

(Red Hat : false like its color, blue.)

\footnotetext{
${ }^{1}$ See : "Not just a HR trend". Behind the curtains of diversity : a statistical analysis of role distribution and hiring practices at a technology company.
} 